\title{
Occurrence of Triatoma costalimai (Hemiptera: Reduviidae) in different environments and climatic seasons: a field study in the Brazilian savanna
}

\author{
Fernanda Machiner ${ }^{[1]}$, Rebecca Martins Cardoso ${ }^{[1]}$, Cleudson Castro ${ }^{[1]}$ and Rodrigo Gurgel-Gonçalves ${ }^{[1],[2]}$
}

\begin{abstract}
[1]. Núcleo de Medicina Tropical, Faculdade de Medicina, Universidade de Brasília, Brasília, DF. [2]. Laboratório de Parasitologia Médica e Biologia de Vetores, Faculdade de
\end{abstract} Medicina, Universidade de Brasília, Brasília, DF.

\begin{abstract}
Introduction: Trypanosoma cruzi-infected specimens of Triatoma costalimai have been detected in domiciliary units of Central Brazil, thereby maintaining the potential risk of vectorial transmission of Chagas disease. The aim of this study was to determine the occurrence and natural infection of $T$. costalimai in different environments (gallery forest, dry forest and peridomicile) and climatic seasons (wet and dry), in the municipality of Mambaí, State of Goiás, Brazil. Methods: Triatomines were captured in October 2010 and in June 2011, employing two different methods (manual capture and mouse-baited adhesive traps). The insects were later separated by sex and nymphal stage, counted and examined parasitologically by abdominal compression and microscopic analysis of feces. Results: Triatoma costalimai was found in three environments and in the two seasons studied. Overall, capture success of 900 traps and 60 blocks of rocks inspected was $5.8 \%$ and $11.7 \%$, respectively. The occurrence of $T$. costalimai was higher among rocks in the peridomicile, where $97 \%$ of the 131 specimens were captured. The proportion of nymphs (98\%) was much higher than that of adults, which were only detected in peridomicile. Most (95\%) insects were captured during the wet season, with predominance of early-stage nymphs. None of the 43 specimens examined were infected by trypanosomatids. Conclusions: The results indicate a greater occurrence of T. costalimai in peridomiciliary environments and during the wet season in Mambaí, Goiás, highlighting the synanthropic behavior of this triatomine species in one area of the Brazilian savanna and the importance of entomological surveillance.
\end{abstract}

Keywords: Triatominae. Rocky habitats. Triatoma costalimai. Brazilian savanna. Brazil.

\section{INTRODUCTION}

After Brazil was declared free from Chagas disease transmission by the domestic vector Triatoma infestans (Klug, 1834), the difficulty in consolidating vector control has been the generalized occurrence of wild triatomine species that invade human dwellings sporadically ${ }^{1,2}$. Ecological aspects of these species must be studied for a better understanding and monitoring of the process of domiciliation, which are fundamental for strengthening entomological surveillance.

Among the species of wild triatomines that invade houses in Brazil is Triatoma costalimai Verano \& Galvão, 1959, the biology of which is poorly understood. This species was described from specimens captured in limestone in peridomiciliary environments in the municipality of Taguatinga, State of Tocantins ${ }^{3}$. Triatoma costalimai specimens are still being captured in domiciliary units in municipalities in the southeast of Tocantins ${ }^{4}$ and northeast of Goiás $5^{5,6}$ with significant rates of infection by Trypanosoma cruzi Chagas, 19097, , thereby maintaining the potential risk of vectorial transmission of Chagas disease.

In a pioneer study on the ecology of T. costalimai, Mello ${ }^{9}$ noted the occurrence of this species in rocky habitats adjacent to gallery

\footnotetext{
Address to: Dr. Rodrigo Gurgel Gonçalves. Lab Parasitologia Médica e Biologia de Vetores/Área de Patologia/FM/UnB. Campus Universitário Darcy Ribeiro, Caixa Postal 4569, Asa Norte, 70904-970 Brasília, DF, Brasil.

Phone: 5561 3107-1786

e-mail: rgurgel@unb.br

Received in 07/12/2011

Accepted in 23/03/2012
}

forests of the Brazilian savanna and also indicated associations of T. costalimai with lizards, rodents (Calomys callosus Rengger, 1830 and Trichomys aperoides Lund, 1839), and marsupials (Didelphis albiventris Lund, 1840) in this environment. However, there has been no detailed information regarding the occurrence of $T$. costalimai in other environments (such as dry forests) and in different seasons. Such information may clarify the synanthropic potential of T. costalimai and consequently support strategies for the surveillance of Chagas disease vectors in Central Brazil. In this context, the objective of this study was to determine the occurrence and natural infection of T. costalimai in rock habitats in different environments (gallery forest, dry forest, and peridomicile) and climatic seasons (wet and dry) in the municipality of Mambaí, State of Goiás, Brazil.

\section{METHODS}

\section{Study area}

The municipality of Mambaí is located in northeast of Goiás (4606'36"W, 1421'48'S) about 320km from Brasília, Federal District, Brazil. It has an estimated population of 6,883 people ${ }^{10}$, in an area of $859,555 \mathrm{~km}^{2}$. The municipality is inserted in the speleological district of São Domingos, a karstic region with caves, canyons, cliffs and ruiniform landscapes produced by the geological action of groundwater on soluble rocks ${ }^{11}$. This region has an annual average rainfall of $1,500 \mathrm{~mm}$ and an average temperature of $23^{\circ} \mathrm{C}$. The municipality is inserted in the Brazilian savanna biome, with two distinct seasons: a dry season from May to September, and a wet season from October to April. The latter presents the highest temperature 
and precipitation values ${ }^{12}$. Savannas, gallery forests and dry forests are found within the municipality ${ }^{13}$. In Mambaí, the entomological surveillance maintains a community participation strategy with a network of triatomines information posts (PITs) in schools and health care units.

Sampling was conducted in three environments: a) dry forests - forests that have no association with watercourses and are characterized by different levels of falling leaves during the dry season; b) gallery forests - forests that follow small rivers and streams, forming narrow corridors over the watercourse and showing no significant falling leaves during the dry season ${ }^{14}$; and c) peridomicile - considered the environment within a radius of 100 meters around a human domicile. All these environments had limestone rock formations, where insects were collected.

\section{Triatomine collection and parasite detection}

The insects were collected in October 2010 (wet season) and in June 2011 (dry season). Limestone rock formations present in each environment were georeferenced and blocks of rocks were sampled using two sampling methods for triatomines: manual capture and mouse-baited adhesive traps ${ }^{15}$. Manual capture was carried out in 60 blocks of rocks set in 20 blocks per environment, 10 in each climatic season. The blocks were raised with the support of iron levers, and insects found in crevices and holes between fragments of rock were collected with tweezers. Traps were placed in openings between blocks of rocks late in the afternoon and retrieved early the next morning; they were left in the rocks for approximately 12 hours. A total of 300 traps were set in each environment (150 traps in each season), for a total capture effort of 900 traps (450 traps in each season). We spent three days to capture triatomines in each environment. All insects collected were placed in plastic recipients, properly identified with the place and date of capture. Triatomines were grouped by sex and nymphal stage and identified morphologically with the Lent and Wygodzinsky. ${ }^{16}$ key The parasitological research was conducted through abdominal compression of triatomines and subsequent examination of fresh feces under a light microscope to detect natural infection by trypanosomatids.

\section{Data analysis}

In each environment the following entomological data were analyzed: percentage of infested rocks using manual capture; percentage of positive trap-nights; number of triatomines captured; number of triatomines per infested rock; number of triatomines per positive trap; percentage of nymphs captured; percentage of triatomines engorged; number of triatomines examined and infected. Differences between the proportions of insects collected in the different environments and climatic seasons were evaluated using the chi-square test, considering $\mathrm{p}<0.05$ as statistically significant.

\section{Ethical considerations}

The study followed the Ethical Principles in Animal Experimentation developed by the Brazilian College of Animal Experimentation (COBEA), which were approved by the Ethics Committee on Animal Use at the Faculty of Medicine, University of Brasilia (UnB).

\section{RESULTS}

The overall capture success of the 900 traps and 60 blocks of rocks surveyed was $5.8 \%$ and $11.7 \%$, respectively. T. costalimai was the only triatomine species detected. The occurrence of T. costalimai differed among the environments sampled; the proportion of positive traps was greater in a peridomiciliary environment compared to gallery forest $\left(\chi^{2}=49.0 ; p<0.01\right)$ and dry forest $\left(\chi^{2}=43.3 ; p<0.01\right)$. The number of specimens of $T$. costalimai was also greater in rocks in peridomiciliary environments associated to pigpens and henhouses, where $97 \%$ of the 131 specimens were captured (Table 1). The proportion of nymphs was much greater than that of adults, which were all males and which were only detected in a peridomiciliary environment. Engorged insects were only detected in peridomicile (Table 1), especially using the manual capture method. None of the 43 specimens examined were infected by trypanosomatids (Table 1).

The occurrence of $T$. costalimai varied by climatic season, as found by both the trapping method $\left(\chi^{2}=33.8 ; p<0.01\right)$ and

TABLE 1 - Entomological data of Triatoma costalimai in different environments (gallery forest, dry forest and peridomicile) and climatic seasons (dry and wet) in Mambaí, State of Goiás, Brazil, 2010-2011.

\begin{tabular}{|c|c|c|c|c|c|c|}
\hline \multirow[b]{2}{*}{ Entomological data } & \multicolumn{2}{|c|}{ Gallery forest } & \multicolumn{2}{|c|}{ Dry forest } & \multicolumn{2}{|c|}{ Peridomicile } \\
\hline & dry & wet & dry & wet & dry & wet \\
\hline Infestation (\%)* & 0.0 & 0.0 & 0.0 & 0.0 & 10.0 & 60.0 \\
\hline Trap-nights positive (\%)** & 0.0 & 1.0 & 0.0 & 2.0 & 3.0 & 30.0 \\
\hline Bugs captured by trapping (n) & 0 & 1 & 0 & 3 & 5 & 92 \\
\hline Bugs captured manually (n) & 0 & 0 & 0 & 0 & 1 & 29 \\
\hline Bugs/infested rock & 0 & 0 & 0 & 0 & 1 & 5 \\
\hline Bugs/positive trap & 0 & 1 & 0 & 1 & 1 & 2 \\
\hline Nymphs (\%) & $* * *$ & 100.0 & $* * *$ & 100.0 & 66.0 & 99.0 \\
\hline Engorged bugs (\%) & $* * *$ & 0.0 & $* * *$ & 0.0 & 0.0 & 20.0 \\
\hline Examined bugs $(n)$ & 0 & 0 & 0 & 0 & 6 & 37 \\
\hline Infected bugs ( $\mathrm{n}$ ) & 0 & 0 & 0 & 0 & 0 & 0 \\
\hline
\end{tabular}

${ }^{*}$ number of rocks infested/sampled; 10 blocks of rocks were sampled in each climatic season. ${ }^{* *} 150$ trap-nights were used in each climatic season using the manual capture method. ${ }^{* * *}$ no bugs captured. 
the manual capture method $\left(\chi^{2}=4.0 ; p=0.04\right)$. The percentages of positive traps and of blocks of rocks infested by T. costalimai were higher in the wet season (Table 1). Moreover, most (95\%) insects were captured in the wet season, with a predominance of nymphs I (Figure 1).

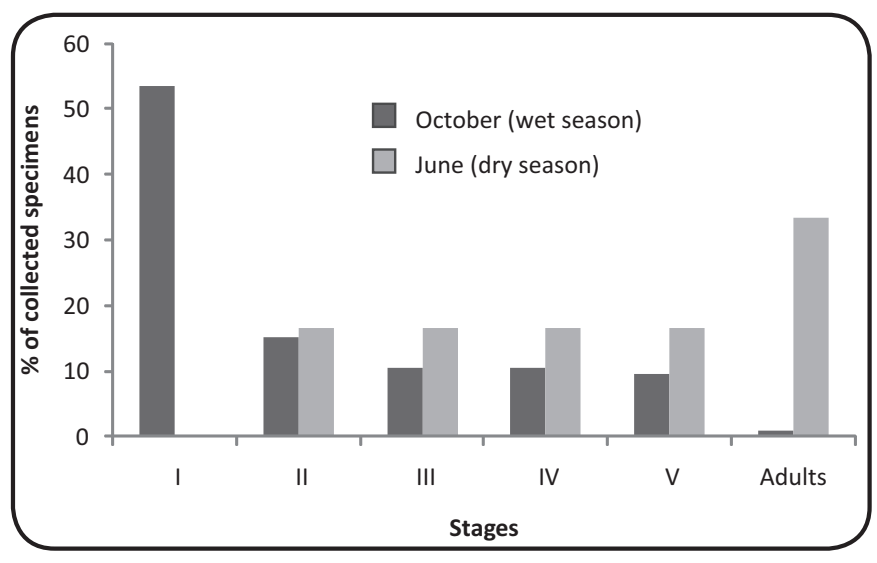

FIGURE 1 - Percentage of specimens of Triatoma costalimai collected in Mambaí, State of Goiás in October (wet season) and June (dry season), by stage of development.

\section{DISCUSSION}

Limestone rocks had already been reported as habitats for $T$. costalimai in areas of gallery forests in Mambaí, Goiás ${ }^{9}$. Our study confirms the occurrence of $T$. costalimai in this environment and also indicates that the species occurs in blocks of rocks in dry forests and, especially, in peridomiciliary environments. The results also suggest, for the first time, a difference in the occurrence of $T$. costalimai in different climatic seasons in one area of the Brazilian savanna.

Between 1979 and 1981, Mello sampled 22 blocks of rocks by manual collection, obtaining 43 nymphs in 10 of them (insect/infested rock $=4.3$ ). We detected 30 insects in 7 blocks of rocks (insect/infested rock $=4.3$ ), using the same sampling method. The higher occurrence of T. costalimai in peridomicile relative to the wild environment (gallery forest and dry forest) is an indicator of the synanthropic potential of this species. In the peridomicile studied, many engorged specimens were found in rocks next to pigpens and henhouses, indicating that T. costalimai can feed on domesticated animals such as poultry and pigs. The occurrence of $T$. costalimai inside domiciles was already detected by Oliveira \& Silva ${ }^{6}$, but there is little evidence of colonies inside human dwellings ${ }^{17}$.

According to Lorosa et al. ${ }^{8}$, the feeding habits of this species are varied. A number of food sources have been found in the intestinal contents among specimens sampled in northern Goiás, including rodents, opossums, lizards, horses, armadillos and birds. The abundant and continuous food source present in the peridomicile could explain the higher occurrence of $T$. costalimai in this environment. According to Forattini et al. ${ }^{18}$, environments with dense vegetation are not favorable for population growth of other species common to the Brazilian savanna, such as Triatoma sordida Stål, 1859. The presence of predators and the lower occurrence of continuous food sources (and, therefore, greater competition for food) could limit the development of $T$. costalimai colonies in the wild environment. On the other hand, open areas, changed by human intervention and with the presence of animal breeding, may offer greater opportunities for feeding and development of this triatomine species. Similar studies in other areas of the Brazilian savanna may confirm the differences in the spatial occurrence of $T$. costalimai detected in this study.

Our results showed that most specimens of $T$. costalimai were captured in October, with predominance of nymphs I, indicating the occurrence of reproductive processes and oviposition in the beginning of the wet season. According to Schofield et al. ${ }^{17}$, the life cycle of $T$. costalimai, maintained at $27 \pm 3$ O C with $40-80 \%$ Rh conditions and fed fortnightly, is over one year. Thus we would expect the emergence of adults in the second semester of the following year. The detection of nymphs II in June does not necessarily imply reproductive events during the dry season, since T. costalimai may remain in this nymphal stage for up to 145 days. In the case of other triatomine species such as Panstrongylus megistus (Burmeister, 1834), studies in different regions of Brazil indicate that the invasion of specimens in domiciles occurs more in the wet season, especially during the last quarter of the year ${ }^{19-21}$. The increase of temperature seen in areas of the Brazilian savanna during this period ${ }^{22}$ could stimulate the reproduction, dispersal and development of $T$. costalimai colonies, as already observed for other triatomine species ${ }^{23,24}$. Future studies on temporal occurrence of $T$. costalimai in other areas and with greater capture effort in each climatic season may confirm the results obtained in this study. These studies are essential to clarify the population dynamics of triatomines and may support entomological surveillance strategies, such as the determination of best periods for control practices or application of measures to prevent infestation or reinfestation of areas already controlled ${ }^{25}$.

In this study, specimens of T. costalimai infected by trypanosomatids were not detected. However, only $33 \%$ of the insects captured were examined, as the others were dry or dead at the moment of examination, making the removal of the intestinal contents unfeasible. Moreover, more than half of the specimens captured were nymphs I, which decreases the probability of detection of infected triatomines. The occurrence of natural infection of T. costalimai by T. cruzi in Mambaí has been evidenced by Mello and Borges ${ }^{7}$. Trypanosoma cruzi infection rates of T. costalimai detected in other municipalities of northern Goiás and southeast Tocantins were $13.5 \%$ and $75 \%$, respectively $y^{4,8}$, indicating that $T$. costalimai maintains a potential risk of vectorial transmission of Chagas disease. Future studies using molecular tools for detection of $T$. cruzi ${ }^{26}$ may determine more accurately the infection rate of $T$. costalimai in rock habitats at Central Brazil.

The results of this study indicate that limestones present in the peridomicile are favorable environments for the development of T. costalimai colonies in Mambaí, State of Goiás, highlighting the synanthropic behavior of this triatomine species. Therefore, we recommend that residents of these areas avoid building houses next to rocks, as well as keeping domesticated animals near these rocks. We also suggest the improvement of the PIT network in the municipality, and community encouragement, based on educational actions, for active participation of inhabitants in entomological surveillance. These preventive measures may decrease the risk of domiciliary infestation by T. costalimai and, consequently, decrease the probability of transmission of T. cruzi to humans in these areas. 


\section{ACKNOWLEDGMENTS}

We are grateful to Marcelo Lima Reis, Sérgio Rubens Lacerda de Morais, Luiz Carlos Nunes de Andrade and José Barbosa Bezerra for their support in the field work, and to Aline da Fonseca Rosa for her assistance in the parasitological examination of insects. We also wish to express our thanks to Catarina Macedo Lopes for providing the adhesive tapes used in traps and to Teresa Cristina Monte Gonçalves, Marta Isabel Wolff Echeverri and César Augusto Cuba Cuba for their criticism and suggestions.

\section{CONFLICT OF INTEREST}

The authors declare that there is no conflict of interest.

\section{FINANCIAL SUPPORT}

Coordenação de Aperfeiçoamento de Pessoal de Nível Superior.

\section{ABSTRACT IN PORTUGUESE}

\section{Ocorrência de Triatoma costalimai (Hemiptera: Reduviidae) em diferentes ambientes e estações climáticas: um estudo de campo em área de Cerrado}

Introdução: Espécimes de Triatoma costalimai infectados por Trypanosoma cruzi têm sido detectados em unidades domiciliares no Brasil Central, mantendo o risco potencial de transmissão vetorial da doença de Chagas. Objetivou-se determinar a ocorrência e infecção natural de T. costalimai em habitats rochosos em diferentes ambientes (mata de galeria, mata seca e peridomicílio) e estações climáticas (chuvosa e seca), no município de Mambaí, Estado de Goiás, Brasil. Métodos: Os triatomíneos foram capturados em outubro de 2010 e junho de 2011 usando dois métodos (coleta manual e armadilhas adesivas com isca animal) e posteriormente foram separados por estádio e sexo, contabilizados e examinados parasitologicamente por compressão abdominal e análise microscópica das fezes. Resultados: Triatoma costalimai foi detectado nos três ambientes e nas duas estações amostradas. 0 sucesso total de captura das 900 armadilhas e 60 blocos de rochas inspecionados foi de $5,8 \%$ e $11,7 \%$, respectivamente. A ocorrência de $T$. costalimai foi maior em rochas do peridomicílio, onde $97 \%$ dos 131 espécimes foram capturados. A proporção de ninfas (98\%) foi muito superior à de adultos, os quais só foram detectados no peridomicílio. A maioria (95\%) dos insetos foi capturada na estação chuvosa, com predominância de ninfas I. Nenhum dos 43 espécimes examinados estava infectado por tripanosomatídeos. Conclusões: Os resultados indicam maior ocorrência de $T$. costalimai em ambiente peridomiciliar e na estação chuvosa em Mambaí, Goiás, salientando o comportamento sinantrópico dessa espécie de triatomíneo em uma área do cerrado Brasileiro e a importância da vigilância entomológica.

Palavras-chaves: Triatominae. Habitats rochosos. Triatoma costalimai. Cerrado. Brasil.

\section{REFERENCES}

1. Guhl F, Pinto N, Aguilera G. Sylvatic triatominae: a new challenge in vector control transmission. Mem Inst Oswaldo Cruz 2009; 104 (supl I):71-75.

2. Silveira AC, Dias JCP. O controle da transmissão vetorial. Rev Soc Bras Med Trop 2011; 44 (supl II):52-63.
3. Verano OT, Galvão AB. Triatoma costalimai sp.n. Rev Bras Malariol D Trop 1958; 10:199-205.

4. Gonçalves TCM, Sampaio IA, Ramos LB, Gomes ACF, Maia AAS, Dantas EC, et al. Investigação sobre a fauna de triatomíneos no sudeste de Tocantins. Rev Soc Med Trop 2009; 42 (supl II):47.

5. Silva IG, Silva JL, Silva HHG, Camargo M, Moura AF, Elias M, et al. Distribuição dos vetores da tripanossomíase americana capturados no ambiente domiciliar no estado de Goiás no período de 1984/88. An Soc Entomol Bras 1992; 21:139-154.

6. Oliveira AW, Silva IG. Distribuição geográfica e indicadores entomológicos de triatomíneos sinantrópicos capturados no Estado de Goiás. Rev Soc Bras Med Trop 2007; 40:204-208.

7. Mello DA, Borges MM. Initial discovery of Triatoma costalimai naturally infected with Trypanosoma cruzi: study of the biological aspects of an isolated sample. Mem Inst Oswaldo Cruz 1981; 76:61-69.

8. Lorosa ES, Andrade RE, Santos SM, Pereira CA, Vinhaes MC, Jurberg J. Estudo da infecção natural e fontes alimentares de Triatoma costalimai Verano \& Galvão, 1959, Rhodnius neglectus Lent, 1954 e Psammolestes tertius Lent \& Jurberg, 1965 do estado de Goiás, Brasil, através da técnica de precipitina. Entomol Vect 1999; 6:405-414.

9. Mello DA. Roedores, marsupiais e triatomíneos silvestres capturados no município de Mambaí-Goiás. Infecção natural pelo Trypanosoma cruzi. Rev Saude Publica 1982; 16:282-191.

10. Instituto Brasileiro de Geografia e Estatística (IBGE) [Internet]. Censo 2010. Brasília: IBGE; 2010. [Cited 2010 October 17] Available from: http://www.ibge.gov.br/.

11. Karmann I, Sanchez LE. Distribuição das Rochas Carbonáticas e Províncias Espeleológicas do Brasil. Espeleo-Tema 1979; 13:105-167.

12. Klink CA, Machado RB. Conservation of Brazilian Cerrado. Conserv Biol 2005; 19:707-713.

13. Zapata MTG, Marsden PD. Chagas' disease: control and surveillance through use of insecticides and community participation in Mambai, Goias, Brazil. Bull Pan Am Health Organ 1993, 27:265-279.

14. Ribeiro JF, Walter BMT. Fitofisionomias do bioma cerrado. In: Sano SM, Almeida SP, Ribeiro JF, editors. Cerrado: ecologia e flora. Brasília: Embrapa Cerrados; 2008. p 151-212.

15. Noireau F, Abad-Franch F, Valente SA, Dias-Lima A, Lopes CM, Cunha V, et al. Trapping triatominae in silvatic habitats. Mem Inst Oswaldo Cruz 2002; 97:61-63.

16. Lent H, Wygodzisnky P. Revision of the Triatominae (Hemiptera - Reduviidae) and their significance as vectors of Chagas' disease. Bull Amer Mus Natur Hist 1979; 163:123-520

17. Schofield CF, Marsden PD, Virgens D. Notes on the biology of Triatoma costalimai Verano \& Galvão 1958 (Hemiptera; Reduviidae; Triatominae). An Soc Entomol Bras 1980; 9:295-301.

18. Forattini OP, Ferreira AO, Silva EOR, Rabello EX, Santos JLF. Aspectos ecológicos da tripanossomose americana. II- Distribuição e dispersão local de triatomíneos em ecótopos naturais e artificiais. Rev Saude Publica 1971; 5:163-191.

19. Forattini OP, Ferreira AO, Rabello EX, Barata JMS, Santos JLF. Aspectos ecológicos da tripanossomíase americana: XX - Desenvolvimento e ciclos anuais de colônias de Panstrongylus megistus em ecótopos artificiais, no ambiente peri e extradomiciliar. Rev Saude Publica 1984; 18:30-40.

20. Mendes PC, Lima SC, Paula MBCP, Souza AA, Rodrigues EAS, Limongi JE. Doença de Chagas e a distribuição espacial de triatomíneos capturados em Uberlândia, Minas Gerais - Brasil. Hygeia. Rev Bras Geo Med Saude 2008; 3:176-204.

21. Maeda MH, Knox MB, Gurgel-Gonçalves R. Occurrence of synanthropic triatomines (Hemiptera: Reduviidae) in the Federal District, Brazil. Rev Soc Bras Med Trop 2012; 45:71-76.

22. Silva Júnior MC, Felfili JM, Nogueira PE, Rezende AV. Análise florística das Matas de Galeria no Distrito Federal. In: Ribeiro JF, editor. Cerrado: Matas de Galeria. Brasília: Embrapa; 1998. p. 53-84.

23. Lehane MJ, McEwen PK, Whitaker CJ, Schofield CJ. The role of temperature and nutritional status in flight initiation by Triatoma infestans. Acta Trop 1992; 52:27-38. 
24. Gorla DE, Catalá SS, Grillo MP. Efecto de la temperatura sobre la distribución de Triatoma infestans y el riesgo de transmisión vectorial de la enfermedad de Chagas en Argentina. Acta Toxicol Argent 1997; 5:36-39.

25. Forattini OP, Santos JLF, Ferreira OA, Rocha e Silva EO, Rabello EX. Aspectos ecológicos da tripanossomíase americana: XVI - dispersão e ciclos anuais de colônias de Triatoma sordida e de Panstrongylus megistus espontaneamente desenvolvidas em ecótopos artificiais. Rev Saude Publica 1979; 13:299-313.
26. Cura Cl, Mejía-Jaramillo AM, Duffy T, Burgos JM, Rodriguero M, Cardinal MV, et al. Trypanosoma cruzi I genotypes in different geographic regions and trans-mission cycles based on a microsatellite motif of the intergenic spacer of spliced leader genes. Int J Parasitol 2010; 40:1599-1607. 